\title{
Implementasi Persetujuan TRIPs dalam Undang-Undang Hak Cipta Indonesia
}

\author{
Nandang Sutrisno
}

\begin{abstract}
Abstrak
The enactment of Copy Rights Law 1997 No. 12 has been the effort of Indonesia to harmonize intellectual property rights laws with the Agreement on Trade Related Aspects of Intellectual Property Rights (TRIPS). The Law embodies some substantial changes so that they have been relevant and significant as the implementation of TRIPS. The changes have oriented toward new norms, higher standards and strict law enforcement. The most important thing, however, has been the social significant of the law in order to be effective.
\end{abstract}

\section{Pendahuluan}

Persetujuan tentang Aspek-aspek Hak Atas Kekayaan Intelektual (HAKI) yang terkait dengan Perdagangan (Agreement on TradeRelated Aspects of Intellectual Property Rights; TRIPS) yang merupakan bagian yang tidak terpisahkan dari Persetujuan Pembentukan Organisasi Perdagangan Dunia (Agreement Establishing the World Trade Organization) telah diratifikasi berdasarkan Undang-undang Nomor 7 Tahun 1994. Implikasinya, bahwa Indonesia harus melakukan harmonisasi dengan ketentuan-ketentuan yang ada di dalamnya.

Meskipun ketentuan-ketentuan TRIPs baru akan berlaku bagi Indonesia, sebagai negara sedang berkembang, pada tahun 2000, namun upaya harmonisasi telah secara dini dilakukan. Salah satu bentuk upaya har- monisasi tersebut adalah dengan dikeluarkannya Undang-undang Nomor 12 Tahun 1997 tentang Perubahan atas Undang-undang Nomor 6 Tahun 1982 tentang Hak Cipta sebagaimana telah diubah dengan Undangundang Nomor 7 Tahun 1987. Permasalahannya adalah, sejauhmana relevansi dan signifikansi implementasi TRIPs dalam undangundang tersebut.

\section{Latar Belakang TRIPs}

TRIPs sebenarnya merupakan isu baru dalam Persetujuan Umum tentang Tarif dan Perdagangan (General Agreement on Tariffs and Trade; GATT) yang dimasukkan melalui Putaran Uruguay yang berjalan dari tahun 1986 sampai tahun 1994. Sebelumnya per- 
soalan HAKI berada di bawah pengaturan sejumlah perjanjian multilateral yang diadministrasikan oleh forum lain, seperti World Intellectual Property Organization (WIPO), UNESCO dan UNCED.'

WIPO yang berkantọr pusat di Jenewa mengadministrasikan sebanyak 25 perjanjian multilateral tentang HAKI yang terdiri dari perjanjian di bidang Hak Cipta sebanyak 8 buah, bidang Hak Atas Kekayaan Industri sebanyak 17 buah. Selain itu WIPO juga mengadministrasikan konvensi pembentukan WIPO (1967) sendiri. UNESCO mengelola Universal Copyright Convention, dan UNCED mengelola satu perjanjian yang sebenarnya tidak secara khusus mengatur HAKI, tetapi HAKI merupakan salah satu aspek yang diaturnya, yaitu Biodiversity Convention.

Masuknya masalah HAKI ke dalam GATT, sebenarnya merupakan usulan dari negaranegará industri agar HAKI mereka lebih terjamin perlindungannya dalam globalisasi perdagangan dengan alasan bahwa penegakan hukum melalui Mahkamah Intemasional yang dianut dalam perjanjian-perjanjian tersebut dianggap tidak efektif. ${ }^{2}$ Negara-negara industri memandang bahwa mekanisme penyelesaian sengketa melalui GATT akan lebih efektif, karena dimungkinkannya untuk melakukan pembalasan (retaliation) dan pembalasan silang (cross retaliation) yang berupa sanksisanksi perdagangan yang dikenakan terhadap barang-barang ekspor negara yang melakukan pelanggaran TRIPs. ${ }^{3}$

Mestinya negara-negara maju melakukan penyempurnaan mekanisme penegakan hukum dalam kerangka WIPO, tetapi mereka tidak melakukannya mengingat sistem pengambilan keputusan pada lembaga tersebut didasarkan pada pemungutan suara yang jelas akan mengalahkannya karena jumlah mereka jauh lebih kecil daripada negara-negara berkembang. Sedangkan di dalam GATT, yang basisnya adalah negosiasi, yang memurigkinkan adanya saling menerima dan memberi akses di antara negara-negara anggota, negara-negara industri menganggap bahwa kepentingannya lebih terjamin karena mereka dapat memainkan posisi tawarnya (bargaining power) yang kuat. Masuknya masalah HAKI ke dalam GATT mendapat tentangan yang keras dari negara-negara sedang berkembang. Mereka memandang bahwa tidak ada hubungan antara HAKI dengan perdagangan, dan oleh karenanya GATT bukan forum yang tepat untuk merundingkan HAKI. ${ }^{4}$ Masuknya HAKI ke dalam GATT justru akan merusak sistem perdagangan itu sendiri karena akan

'Bambang Kesowo."Implementasi Persetujuan TRIPs dalam Hukum HakAtas Kekayaan Intelektual Nasional'. Makalah dalam Penataran Hukum Aktivitas Perniagaan Internasional. Fakultas Hukum Universitas Padjajaran. Bandung. 29 Juli 1997. Him.23.

${ }^{2}$ Ibid. HIm. 22. Lihat juga Ronald J. Vles et al. Creators and Performers. 1992. "dalam Dennis Campbell dan Russel E. Carlisle ed. The Transnational Person: Private Rights in the International Bussiness Community. Deventer dan Boston: Kluwer Law and Taxation Publishers. HIm.167.

${ }^{3}$ Martin Khor Kok Peng. 1993. Imperialisme Ekonomi Baru: Putaran Uruguay dan Kedaulatan Dunia Ketiga. Jakarta: PT Gramedia Pustaka Utama dan Konphalindo. HIm. 31.

${ }^{4} /$ bid. HIm. 35. 
menjadi semacam proteksionisme dan akan mengukuhkan posisi monopolistik negaranegara industri dalam perdagangan internasional. Akibat lebih jauh adalah terhambatnya pengembangan dan penyebaran ilmu pengetahuan dan teknologi bagi negara-negara sedang berkembang.

Meskipun dirasa sangat memberatkan, namun negara-negara sedang berkembang, termasuk Indonesia, akhirnya menyepakati TRIPs, karena bargaining power mereka yang sangat lemah.

\section{TRIPS: Kompleks, Komprehensif, Ekstensif: Kompleks, Komprehensif, Ekstensif}

TRIPs merupakan saiah satu perjanjian utama yang dihasilkan dalam Putaran Uruguay yang dimaksudkan untuk mengurangi gangguan dan hambatan terhadap perdagangan internasional, meningkatkan perlindungan yang efektif dan memadai terhadap HAKI serta untuk menjamin bahwa prosedur dan langkah-langkah penegakan hukum HAKI itu sendiri tidak menjadi-hambatan terhadap perdagangan yang absah.

Adapun sasaran yang ingin dicapai oleh TRIPs adalah terpacunya penemuan baru di bidang teknologi dan untuk memperlancar alih serta penyebaran teknologi,dengan tetap memperhatikan kepentingan produsen dan pengguna pengetahuan tentang teknologi dan dilakukan dengan cara yang menunjang kesejahteraan sosial dan ekonomi, dan keseimbangan antara hak dan kewajiban. ${ }^{5}$

Dalam menerapkan ketentuan-ketentuan tentang HAKI, TRIPs juga mengacu kepada prinsip-prinsip umum GATT, seperti National Treatment ${ }^{6}$ dan Most Favoured-Nation. ${ }^{7}$ TRIPs merupakan persetujuan yang sifatnya sangat kompleks, komprehensif dan ekstensif. Hal tersebut dapat terlihat dari beberapa hal pokok yang menjadi cakupan TRIPs, yakni: ${ }^{8}$

1. ketentuan mengenai jenis hak atas kekayaan intelektual yang tercakup dalam perjanjian;

2. standar minimum perlindungan atau rincian ketentuan mengenai sejauh mana perlindungan tersebut harus dilakukan oleh negara peserta;

3. ketentuan mengenai enforcement atau pelaksanaan kewajiban perlindungan HAKl;

4. ketentuan mengenai kelembagaan; dan

5. ketentuan mengenai penyelesaian sengketa.

${ }^{5}$ Pasal 7 Persetujuan TRIPs.

${ }^{6}$ Menurut prinsip ini, setiap negara anggota wajib memberikan perlindungan yang sama terhadap HAKI wargaAnggota lain seperti perlindungan yang diberikan kepada warganegaranya sendiri, dengan memperhatikan beberapa pengecualian yang telah ditentukan. Lihat Pasal 3 TRIPs.

${ }^{7}$ Prinsip ini menyatakan bahwa dalam hal perlindungan HAKI, semua keuntungan, kemanfaatan atau perlakuan istimewa yang diberikan oleh Anggota tertentu kepada warganegara lain harus, seketika dan tanpa syarat, diberikan pula kepada warga Anggota lain, dengan beberapa pengecualian yang telah ditentukan. Lihat Pasal 4 TRIPs.

${ }^{8}$ H.S. Kartadjoemena. 1997. GATT, WTO dan Hasil Uruguay Round. Jakarta: Ul-Press. HIm. 253. 


\section{Jenis HAKI yang Dilindungi}

Sebagaimana yang ditegaskan Pasal 1 ayat (2).TRIPs, ada beberapa jenis HAKI yang tercakup dalam persetujuan, yaitu: hak cipta dan hak-hak terkait lainnya (copy rights and related rights), merek dagang (trademarks); indikasi geografis (geographical indications), desain produk industri (industrial design), paten (patent), desain-layout (topografis) rangkaian elektronik terpadu (Layout-Design (Topographies) of Integrated Circuit), dan perlindungan terhadap informasi yang dirahasiakan (protection of undisclosed information).

Khusus mengenai jenis hak cipta dan hakhak terkait lainnya, Pasal 9 ayat (1) TRIPs merujuk kepada jenis hak cipta yang diatur dalam Pasal 2 Konvensi Bem 1971 yang mencakup segala jenis karya dalam bidang sastra, ilmu pengetahuan dan seni, apa pun cara atau bentuk ekspresinya (expression). Selanjutnya ayat (2) menegaskan bahwa yang dilindungi hak ciptanya adalah karya yang sudah diekspresikan dan tidak hanya berupa ide, prosedur, metode kerja atau konsep matematis sejenisnya.

Program Komputer, baik yang masih berbentuk rumusan awal maupun yang sudah berbentuk kode-kode tertentu, dimasukkan sebagai jenis hak cipta yang dilindungi yaitu sebagai karya sastra menurut Konvensi Ber 1971 (Pasal 10 ayat (1) TRIPs). Demikian pula. Kompilasi Data atau materi lain termasuk yang dilindungi hak ciptanya (Pasal 10 ayat (2) TRIPs). Selain itu Pasal 11 dan Pasal 14 ayat (4) TRIPs memberikan hak kepada pencipta program komputer dan film pertunjukan, produser rekaman musik dan pemegang hak lain atas rekaman musik untuk memberi ijin atau melarang penyewaan hak cipta atas hasil karya mereka (rental rights). Sedangkan Pasal 14 memberikan perlindungan terhadap $\mathrm{Pe}$ laku Pertunjukan, Produser Rekaman (Rekaman Musik) dan Organisasi Siaran.

\section{Standar Minimum Perlindungan}

Jika diamati secara seksama, dapat dilihat bahwa standar perlindungan berbagai bidang HAKI dalam TRIPs merujuk kepada standar minimum yang ada dạlam berbagai konvensi yang sudah ada sebelumnya, terutama yang diadministrasikan oleh WIPO seperti The Paris Convention, The Beme Convention, The Rome Convention, The Treaty on Intellectual Property in Respect of Integrated Circuits (Washington Treaty). TRIPs menentukan normanorma dan standar substantif minimum mengenai sejauh mana perlindungan diberikan dan bagaimana perlindungan tersebut diaplikasikan. Sepanjang tidak bertentangan dengan TRIPs, negara Anggota dapat menerapkan norma-norma dan standar substantif yang melebihi dari yang diharuskan oleh TRIPs dalam hukum nasionalnya.

Dalam bidang Hak Cipta, TRIPs mempergunakan standar minimum The Berne Convention 1971 yang pada prinsipnya memberikan perlindungan seumur hidup kepada si pencipta ditambah 50 tahun setelah ia meninggal, dengan kekecualian menurut jenis hak cipta yang dilindunginya.

\section{Penegakan Hukum}

Dalam bidang penegakan hukum, TRIPs mewajibkan negara Anggota unituk menjamin bahwa prosedur penegakan hukum HAKI tersedia di dalam hukum nasional negara Ang- 
gota masing-masing sehingga memungkinkan dilakukannya gugatan secara efektif terhadap pelangggaran HAKI, termasuk upaya singkat untuk mencegah terjadinya pelanggaran dan upaya yang dapat membuat jera pelanggar HAKl yang lain. Namun prosedur penegakan hukum HAKI harus wajar dan adil, tidak boleh menjadi hambatan terhadap perdagangan yang sah, berbelit-belit atau mahal, atau berlangsung terlalu lama.

Meskipun demikian TRIPs tidak mewajibkan Anggotanya untuk membentuk sistem peradilan khusus yang-berbeda dengan sistem peradilan yang secara umum berlaku dalam rangka penegakan hukum pada umumnya.

Selanjutnya, dalam penegakan hukum HAKI ini, TRIPs juga mengatur persyaratan khusus yang tekait dengan tindakan di tapal batas negara. Dalam hal ini negara Anggota diharuskan untuk mencegah terjadinya pengimporan atau pengeksporan barang-barang hasil pelanggaran HAKI dengan cara penundaan dilepaskannya barang-barang tersebut oleh pabean. Sistem penegakan hukum seperti itu berlaku untuk semua bidang HAKI, termasuk hak cipta.

\section{Kelembagaan}

Mengingat cakupannya yang sangat luas, dalam pelaksanaannya TRIPs memerlukan suatu lembaga baru yang disebut Trade Related Aspects of Intellectual Property Council (Dewan HAKI). Dewan HAKI tersebut berfungsi sebagai pengawas pelaksanaan TRIPs dan pemenuhan kewajiban oleh para Anggota. Selain itu Dewan ini juga berfungsi sebagai forum untuk membicarakan masalah-masalah yang berkaitan dengan TRIPS, untuk me- laksanakan tanggung jawab lain yang ditetapkan oleh Anggota serta memberikan bantuan dalam rangka penyelesaian sengketa. Dewan ini dapat dimanfaatkan oleh semua bidang HAKI, termasuk hak cipta, yang menjadi objek pengaturan TRIPS.

\section{Penyelesaian Sengketa}

Sistem penyelesaian sengketa semua bidang HAKI, termasuk hak cipta, menurut TRIPs mengacu kepada sistem penyelesaian sengketa terpadu (integrated dispute settlement system) dalam kerangka WTO. Dalam rangka penyelesaian sengketa HAKI di antara negara-negara Anggota dan sebagai upaya untuk menjamin kepatuhan terhadap TRIPs, sistem penyelesaian sengketa terpadu membenarkan adanya retaliasi silang (cross retaliation) yang sifatnya lintas sektoral. Suatu pihak dapat menunda konsesi yang diberikannya atau kewajiban lainnya di dalam sektor lain selain dari TRIPs di dalam kasus terjadinya penghapusan dan atau penghilangan keuntungan yang didapat dari persetujuan akibat kebijaksanaan dari negara yang dituntut.

\section{Implementasi TRIPs dalam Undang-undang Hak Cipta}

Dikeluarkannya Undang-undang Nomor 12 Tahun 1997 (Undang-undang Hak Cipta 1997) tentang Perubahan atas Undangundang Nomor 6 Tahun 1982 tentang Hak Cipta Sebagaimana Telah Diubah dengan Undang-undang Nomor 7 Tahun 1987 merupakan upaya pemerintah Indonesia dalam melakukan harmonisasi hukum HAKI Indonesia, di bidang hak cipta, dengan persetujuan 
TRIPs. Hal ini terlihat dengan jelas dari konsideran Undang-undang tersebut bahwa penyesuaian undang-undang hak cipta merupakan konsekuensi logis dari keikutsertaan Indonesia dalam Persetujuan TRIPs. Adapun Undang-undang Hak Cipta 1997 dimaksudkan untuk memberikan perlindungan hukum yang semakin efektif terhadap HAKI, khususnya di bidang Hak Cipta. Sasarannya diarahkan kepada terwujudnya iklim yang lebih baik bagi tumbuh dan berkembangnya semangat mencipta di bidang ilmu pengetahuan, seni dan sastra, yang sangat diperlukan dalam pelaksanaan pembangunan nasional. Undang-undang Hak Cipta 1997 telah memuat beberapa perubahan yang substansial sehingga relevan dan signifikan sebagai implementasi TRIPs. Perubahanperubahan tersebut berorientasi kepada pemuatan norma-norma yang baru, standar yang lebih tinggi dan ketentuan penegakan hukum yang ketat.

Norma-norma baru di sini dapat disebutkan misalnya penambahan pengertian mengenai pelaku, produser rekaman, lembaga penyiaran dan kantor hak cipta; rental rights bagi karya sinematografi, film, video film, dan kewajiban untuk memberi perlindungan kepa- da para performers, producers of phonograms, dan badan-badan siaran. Di samping itu juga terdapat penambahan ketentuan mengajukan ganti rugi atas pelanggaran hak moral, penambahan ketentuan báru mengenai hak-hak yang berkaitan dengan hak cipta.

Standar yang lebih tinggi dapat dithat dari perlindungan bagi komputer program yang harus berlangsung setidaknya selama waktu 50 tahun. Sedangkan penegakan hukum yang ketat dapat dilihat dari tersedianya mekanisme penegakan hukum yang memungkinkan dilakukannya gugatan secara efektif terhadap pelangggaran HAKI sebagaimana yang termuat dalam Bab V. Untuk mendukung penegakan hukum yang efektif selain Penyidik Pejabat Polisi Negara Republik Indonesia, juga Pejabat Pegawai Negeri Sipil tertentu di lingkungan departemen yang lingkup tugas dan tanggung jawabnya meliputi pembinaan Hak Cipta, diberi wewenang khusus sebagai Penyidik sebagaimana dimaksud dalam Undangundang Hukum Acara Pidana Nomor 8 Tahun 1981 untuk melakukan penyidikan tindak pidana di bidang Hak Cipta.

Selanjutnya, dalam penegakan hukum Hak Cipta, TRIPs juga mengatur persyaratan khusus yang tekait dengan tindakan di tapal bataś negara. Dalam hal ini negara Anggota diharuskan untuk mencegah terjadinya pengimporan atau pengeksporan barang-barang hasil pelanggaran HAKI (counterfeit goods) dengan cara penundaan dilepaskannya barang-barang tersebut oleh pabean. Namun pengaturan semacam ini tidak terdapat dalam Undang-undang Hak Cipta 1997, tetapi dalam Undang-undang Nomor 10 Tahun 1995 tentang Kepabeanan, khususnya Pasal 54 sampai dengan Pasal 63 yang mengatur Pengendalian Impor dan Ekspor Barang Hasil Pelanggaran Hak Atas Kekayaan Intelektual. Berdasarkan ketentuan-ketentuan tersebut Pejabat Bea Cukai diberi kewenangan, baik berdasarkan.perintah tertulis Ketua Pengadilan Negeri yang dibuat atas permintaan pemilik/ pemegang hak cipta maupun secara ex-officio, untuk menangguhkan pengeluaran barang impor atau ekspor dari Kawasan Pabean jika berdasarkan bukti yang cukup diduga merupakan hasil pelanggaran hak cipta yang dilindungi di Indonesia. 
Dalam rangka mendukung implementasi TRIPs dalam Undang-undang Hak Cipta 1997, Indonesia telah meratifikasi Konvensikonvensi HAKI pada tahun 1997, termasuk konvensi tentang Hak Cipta. Konvensi-konvensi tersebut adalah: ${ }^{9}$

1. Paris Convention for the Protection of Industrial Property and Convention Establishing the World Intellectual Property Organization yang diratifikasi dengan Kepres No. 15 Tahun 1997:

2. Patent Cooperation Treaty (PCT) and Regulation under the PCT, diratifikasi dengan Kepres №. 16 Tahun 1997.

3. Trademarks Law Treaty yang diratifikasi melalui Kepres No. 17 Tahun 1997

4. Bern Convention for the Protection of Literary and Artistic Work; diratifikasi dengan Kepres No.18 Tahun 1997.

5. WIPO Copyright Treaty, diratifikasi melalui Kepres No. 19 Tahun 1997.

\section{Signifikansi Sosial}

Dengan asumsi bahwa tidak ada perundang-undangan yang betul-betul sempurna, dan tanpa mengabaikan adanya usulan revisi, ${ }^{10}$ implementasi TRIPS dalam bentuk
Undang-undang Hak Cipta 1997 telah cukup memadai. Artinya, norma-norma yang menjadi muatan undang-undang tersebut sebagian besar telah sejalan dengan TRIPs. Tetapi yang tidak kalah pentingnya adalah bagaimana agar undang-undang tersebut memiliki signifikansi sosial yang tinggi di masyarakat kita, sehingga beberapa sasaran dapat tercapai. Pertama, jika Undang-undang Hak Cipta 1997 mempunyai signifikansi sosial yang tinggi, maka pelaksanaannya oleh masyarakat akan efektif. Oleh karena itu perlu adanya sosialisasi" dan edukasi yang efektif pula, mengingat potensi untuk tidak menghormati HAKI, termasuk hak cipta, justru ada pada masyarakat.

Dalam tata pergaulan internasional masyarakat kita dikenal sebagai masyarakat yang kurang menghargai hak atas kekayaan intelektual, termasuk hak cipta. Pelanggaran hak cipta baik yang dimiliki atau dipegang warganegara Indonesia sendiri maupun pihak asing oleh masyarakat Indonesia sudah sampai pada taraf yang mengkhawatirkan. Salah satu hasil penelitian yang dilakukan oleh Business Software Alliance yang dilansir pada tahun 1997 menunjukkan data yang spektakuler, bahwa $93 \%$ software komputer yang beredar di Indonesia pada tahun tersebut adalah hasil bajakan. ${ }^{12}$ Akibat pelanggaran hak cipta atas.

'Lihat Sudargo Gautama dan Rizawanto Winata. 1998. Konvensi-konvensi Hak Milik Intelektual Baru untuk indonesia (1997). Bandung: PT Citra Aditya Bakti.

${ }^{10}$ Ada yang menganggap bahwa UU No. 12, UU No. 13 dan UU No. 14 Tahun 1997 kurang aspiratif dan tidak mengakomodasikan suara masyarakat, dan oleh karena itu ketiganya masih perlu untuk direvisi. Lihat Insan Budi Maulana. "Seputar Tiga RUU HAKI (Kapan Ditetapkan UU Desain Industri, Tata Letak Sirkuit Terpadu \& Rahasia Dagang)". Makalah disampaikan dalam Diskusi Panel yang diselenggarakan oleh Fakultas Hukum Universitas Islam Indonesia Yogyakarta. 30 Juni 1999.

"Insan Budi Maulana. 1997. Sukses Bisnis Melalui Merek, Paten dan Hak Cipta. Bandung: PT Citra Aditya Bakti. HIm. 169.

${ }^{12}$ Republika. 9 Januari 1999. 
software komputer tersebut, khusus yang dimiliki orang atau badan hukum dan terdaftar di Amerika Serikat, telah menimbulkan kerugian sebesar US $\$ 226,8$ selama tahun $1997 .^{13}$ Menurut laporan Media Indonesia, sejak anjloknya kurs Rupiah terhadap Dollar, ada kecenderungan bahwa pelanggaran-pelanggaran HAKI mengalami peningkatan yang signifikan. Pada tahun 1998 sampai awal tahun 1999, Bea Cukai II Bandara SoekarnoHatta telah menggagalkan sebanyak 67.527 unit Compact Disc (CD) bajakan dengan kerugian negara sebesar Rp. 799 milyar. $^{14}$ Pelanggaran-pelanggaran lain seperti pembajakan buku, kaset, VCD dan lain-lain sudah merupakan berita sehari-hari. Pelanggaranpelanggaran di bidang hak cipta tersebut umumnya, selain disebabkan oleh adanya peluang yang ditawarkan oleh kemajuan teknologi informasi dan komunikasi, juga kurangnya pemahaman dan kesadaran hukum masyarakat. ${ }^{15}$

Kedua, signifikansi sosial undang-undang tersebut juga akan membawa dampak bagi para penegak hukum untuk melaksanakan tugasnya secara efektif. Pelanggaran-pelanggaran hak cipta selama ini juga sedikit banyak disebabkan oleh lemahnya penegakan hukum, terutama karena koordinasi dan pemahaman hak cipta di antara aparat penegak hukum. ${ }^{16}$ Untuk itu, tersedianya sumber daya manusia penegak hukum yang qualified, serta sarana dan prasarana yang memadai merupakan kebutuhan yang tidak bisa ditawar.

Ketiga, dengan signifikansi sosial yang tinggi, maka undang-undang tersebut akan dapat berfungsi sebagai alat rekayasa sosial sehingga sasaran TRIPs dan Undang-undang Hak Cipta 1997 tercapai, yakni tumbuh dan berkembangnya semangat mencipta di bidang ilmu pengetahuan, seni dan sastra.

Tanpa tercapainya sasaran ketiga ini, Indonesia tidak akan dapat memainkan peran yang sesungguhnya dalam perdagangan internasional. Dalam perdagangan barang yang berbasis hak cipta dan perdagangan lisensi hak cipta indonesia hanya akan menjadi pengimpor. Ini berarti devisa akan mengalir ke negara-negara lain, khususnya negaranegara yang dunia HAKI-nya sudah maju. Hal ini jelas akan merupakan ancaman yang serius bagi keseimbangan neraca pembayaran Indonesia. Oleh karena itu, budaya HAKI harus terus menerus dikembangkan.

\section{Simpulan}

Jika ketiga sasaran tersebut tercapai berarti bahwa negara kita benar-benar dapat merasakan manfaat keikutsertaannya dalam TRIPs. Meskipun berada dalam fora internasional, Undang-undang Hak Cipta sudah

${ }^{13}$ Bambang Kesowo. "Perlindungan Hak Cipta atas Komputer Program". Sambutan Arahan pada Seminar Hak Cipta atas Program Komputer serta Penggunaannya di Indonesia. diselenggarakan oleh Fakultas Hukum Universitas Atma Jaya. P.T. Microsoft Indonesia dan Perhimpunan Masyarakat HAKI Indonesia. di Yogyakarta. 28 April 1999.

${ }^{14}$ Media Indonesia. 16 Februari 1999.

${ }^{15}$ Wolter Simanjuntak. "Beberapa Permasalahan Penegakan Hukum Bidang Hak Cipta". Masyarakat HAKI. Vol 2. No. 1. 28 April 1999. Him. 8.

${ }^{16} / \mathrm{bid}$. 
seharusnya juga dibentuk dan diimplementasikan dengan memperhatikan dan dengan cara yang paling dapat memenuhi kepentingan nasional. ${ }^{17}$ Tanpa memperhatikan kepentingan nasional tersebut, Undang-undang Hak Cipta hanya akan mengakomodasi kepentingan-kepentingan negara lain dan, oleh karena itu, hanyà akan bermanfaat bagi orang-orang asing.

\section{Daftar Pustaka}

Gautama, Sudargo dan Rizawanto Winata. 1998. Konvensi-konvensi Hak Milik. Intelektual Baru untuk Indonesia (1997). Bandung:Citra Aditya Bakti.

Kartadjoemena, H.S. 1997. GATT, WTO dan Hasil Uruguay Round. Jakarta: UIPress.

Kesowo, Bambang. "Implementasi Persetujuan TRIPS dalam Hukum Hak Atas Kekayaan Intelektual Nasional." Makalah disajikan dalam Penataran Hukum Aktivitas Perniagaan Internasional. Fakultas Hukum Universitas Padjadjaran. Bandung. 29 Juli 1997.

- , "Perlindungan Hak Cipta atas Komputer Program". Sambutan Arahan pada Seminar Hak Cipta Program Komputer serta Penggunaannya di Indonesia. diselenggarakan oleh Fakultas Hukum Universitas Atma Jaya. P.T. Microsoft Indonesia dan Perhimpunan Masyarakat HAKI Indonesia. di Yogyakarta. 28 April 1999.
Maulana, Insan Budi. 1997.Sukses Bisnis Melalui Merek, Paten dan Hak Cipta. Bandung: PT Citra Aditya Bakti.

Seputar Tiga RUU HAKI (Kapan Ditetapkan UU Desain Industri, Tata Letak Sirkuit Terpadu \& Rahasia Dagang). Makalah disampaikan dalam Diskusi Panel yang diselenggarakan oleh Fakultas Hukum Universitas Islam Indonesia Yogyakarta. 30 Juni 1999.

Peng, Martin Khor Kok. 1993. Imperialisme Ekonomi Baru: Putaran Uruguay dan Kedaulatan Dunia Ketiga. Jakarta: PT Gramedia Pustaka Utama dan Konphalindo.

Simanjuntak, Wolter. "Beberapa Permasalahan Penegakan Hukum Bidang Hak Cipta". Masyarakat HAKI. Vol 2. No. 1. 28 April 1999.

Vles, Ronald J. et al., "Creators and Performers," dalam Dennis Campbell dan Russel E. Carlisle ed.. The Trans-national Person: Private Rights in the International Bussiness Community. Deventer dan Bsoton: Kluwer Law and Taxation Publishers. 1992.

World intellectual Property Organization. Background Reading Material on Intellectual Property. Geneva. 1988.

Media Indonesia. 16 Februari 1999.

Republika. 9 Januari 1999.

${ }^{17}$ Lihat Background Reading Material on Intellectual Property. 1988. Geneva: World Intellectal Property Organization. HIm. 33. 